\title{
Addressing lower-priced cigarette products through three-pronged comprehensive regulation on excise taxes, minimum price policies and restrictions on price promotions
}

\author{
Kurt M Ribisl $\odot,{ }^{1}$ Shelley Diane Golden $\odot,{ }^{2}$ Jidong Huang $\odot{ }^{3}$ Michelle Scollo $\oplus^{4}$
}

'Health Behavior, UNC Gillings School of Global Public Health, Chapel Hill, North Carolina, USA ${ }^{2}$ Health Behavior, UNC Chapel Hill, Chapel Hill, North Carolina, USA

${ }^{3}$ School of Public Health Georgia State University, Atlanta, Georgia, USA

${ }^{4}$ Centre for Behavioural Research in Cancer, Cancer Council Victoria, Melbourne, Victoria, Australia

Correspondence to Dr Kurt M Ribisl, Health Behavior, UNC Gillings School of Global Public Health, Chapel Hill, NC 27599, USA; kurt_ribisl@unc.edu

Received 7 June 2021 Accepted 2 December 2021

Check for updates

(C) Author(s) (or their employer(s)) 2022. No commercial re-use. See rights and permissions. Published by BMJ.

To cite: Ribisl KM

Golden SD, Huang J, et al.

Tob Control

2022:31:229-234.

\section{ABSTRACT}

The prices that smokers pay out-of-pocket for their tobacco products ultimately influence their smoking behaviour. Although cigarette excise taxes are arguably the best and most used policy to increase cigarette prices, taxes are only one component of retail cigarette prices. The persistence of lower-priced products, disproportionately purchased by lower-income smokers, in jurisdictions with high excise taxes is an Achilles heel for tobacco tax policy. When governments raise excise taxes, the tobacco industry responds. The industry reduces tax pass-through to minimise the price increases for lower-priced brands and offers price discounts to retailers and coupons to consumers. In addition, smokers who do not quit after tax increases may downshift brands, purchase in bulk or substitute lower-priced tobacco product types. This may be particularly true for price-sensitive smokers, including those with lower incomes. We propose that raising excise taxes will be more effective in reducing the persistence of lower-priced products and income-based smoking disparities when taxes are designed to raise prices frequently and substantially for all products and are combined with (a) minimum price laws and (b) bans on coupons, discounts and other promotions. In combination, these three complementary policies restrict the tobacco industry's ability to undermine the impact of higher excise taxes upon consumer prices. Very few jurisdictions have implemented comprehensive three-pronged tobacco price regulation, but doing so would likely address many of the limitations that come with a sole focus on raising excise taxes.

\section{THE PERSISTENCE OF LOWER-PRICED PRODUCTS IN HIGH-TAX ENVIRONMENTS}

Higher cigarette prices promote smoking cessation, reduce cigarette consumption among those who continue to smoke, prevent former smokers from relapsing and discourage uptake, especially among youth and young adults. ${ }^{1-3}$ Raising tobacco excise taxes to increase retail product prices is one of the WHO's six MPOWER measures, an evidence-based policy package to reverse the tobacco epidemic. ${ }^{4}$ However, the impact of increasing excise taxes can be offset, at least partially, by the tobacco industry's strategic pricing, which in turn facilitates tobacco users' behavioural responses, resulting in the continued availability and use of lower-priced products. Industry pricing strategies have important equity implications, as lower-income tobacco users disproportionately buy and consume products from the discount tier, and are more likely to take advantage of coupons and discounts. ${ }^{5-7}$ Figure $1 \mathrm{~A}$ illustrates the mechanisms through which excise taxes operate to impact income-based smoking inequities, including ways the industry maintains market segmentation.

Tobacco companies have considerable control over the pricing of their products. They can readily offset the impact of excise taxes by using pricereducing strategies and varying tax pass-through based on price segments. The tobacco industry's price-reducing strategies include coupons, price discounts and other strategies aiming to directly reduce the price that smokers pay out-of-pocket for their tobacco products. Coupons are typically collected by some consumers, whereas the price promotions are managed by the retailer and offered to all customers. In 2019, cigarette manufacturers in the USA spent $\$ 5.7$ billion on price discounts, representing their largest category $(74.7 \%)$ of advertising and marketing expenditures. ${ }^{8}$ Data from the Population Assessment of Tobacco and Health Study ${ }^{9}$ in the USA showed that $12.4 \%$ of non-smokers and $36.2 \%$ of adult smokers received a coupon in 2013 and receipt of a coupon predicted progression to regular smoking. Moreover, individuals with incomes lower than $200 \%$ of poverty level were more likely to have used coupons. Research in both the USA and the UK documents a high prevalence of price promotions in the retail environment, ${ }^{10} 11$ and one study found an increase in such promotions following a cigarette excise tax increase. $^{12}$

Differential tax pass-through between premium brands and discount brands is another way in which the tobacco industry offsets the impact of higher excise taxes. Following a new tax increase, a tobacco company could lower the tax pass-through on discount brands while increasing the tax passthrough on premium brands to maintain profits. As a result, tobacco companies can keep the price of discount brands low and minimise the impact of the tax increase on price-sensitive consumers, including people with lower incomes. Several studies examining retail price data in the UK from 2009 to 2019 found despite regular tax increases, average real prices for the lowest-priced cigarette segments remained steady. ${ }^{13-15}$

Following a tax increase, many tobacco users reduce their consumption; a study following an Australian tax increase found that $47.5 \%$ of smokers cut back or tried to quit smoking. ${ }^{16}$ However, when lower-priced products remain on the market, rather 


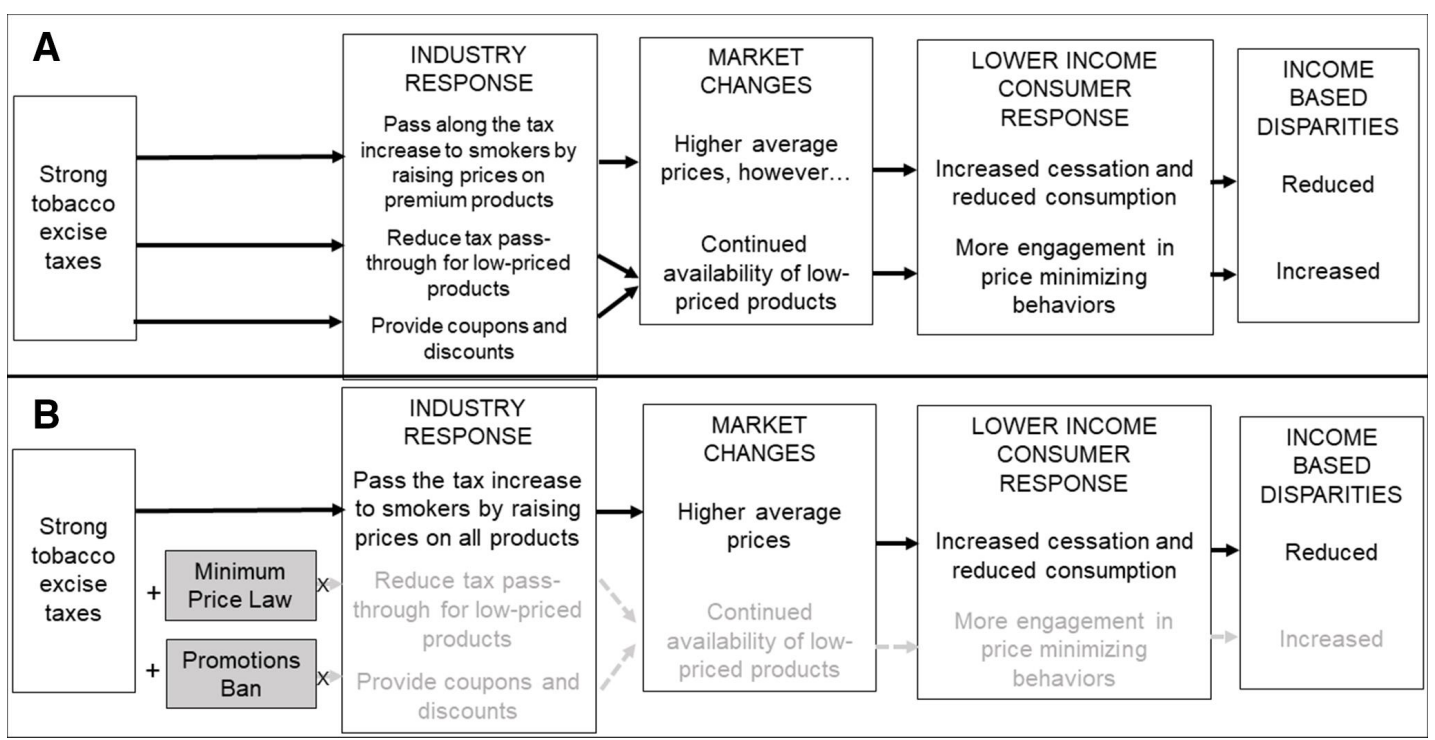

Figure 1 Proposed mechanisms of how tobacco excise taxes influence income-based disparities $(A)$ and the potential impact of a comprehensive three-pronged pricing approach (B).

than quitting or cutting down, some smokers are instead able to keep smoking by engaging in one or more price-minimising behaviours, ${ }^{17} 18$ such as shopping at lower-priced outlets ${ }^{19}$ or purchasing lower-priced product types or brands. ${ }^{19}$ In the Australian study, $11.4 \%$ of smokers engaged in these price-minimising behaviours. ${ }^{16}$ Price-sensitive lower-income smokers are more likely to quit or cut back on their smoking in response to tax increases, but also are more likely to engage in price-minimising behaviours. ${ }^{6}$

\section{PROPOSAL FOR A THREE-PRONGED PRICE POLICY}

To eliminate the persistence of lower-priced products in the face of tax increases, a more comprehensive approach to pricing policy is warranted. Below we outline a three-pronged approach that combines regular, large increases in specific excise taxes with minimum pricing policies and bans on coupons and promotions. The ways in which these policies limit the industry and consumer responses described above are illustrated in figure 1B. In this paper, we focus on the application of these policies to combustible cigarettes and cigars, as well as roll-your-own (RYO) tobacco. Application of these policies to other tobacco products is certainly possible, but requires additional attention to product definition, package sizing and relative product harm.

\section{REGULAR LARGE INCREASES IN A SIMPLE SPECIFIC EXCISE DUTY APPLIED EQUALLY TO ALL COMBUSTIBLE PRODUCTS}

The most straightforward way for governments to address the problem of low tobacco prices is to simply increase tobacco excise taxes. ${ }^{20}$ When excise duty increases, tobacco companies usually increase manufacturer's prices to maintain profits in anticipation of the expected falls in consumption. Both the increased excise duty and increased manufacturer's prices increase wholesale prices. Similarly, wholesalers and retailers also seek to increase prices as much as they are able to so as to maintain revenue or at least minimise loss of revenue in a scenario where consumption is expected to fall. ${ }^{21}$ In some cases, prices go up by more than the magnitude of the tax increase. ${ }^{121521}$ Consequently, a tobacco tax increase will increase tobacco prices, at least on average, across the tobacco market.
To maximise effectiveness of tax increases, it is necessary to ensure increases in the prices of lower-priced, as well as more expensive, tobacco products. Three design features are important. First, tax levels should be based on the quantity of tobacco (ie, specific excise taxes) rather than the value of the tobacco product (ie, ad valorem taxes). ${ }^{22}$ By design, ad valorem taxes will be lower on lower-priced products than on more expensive ones, whereas specific excise taxes are designed to be the same for all products of a particular type. Second, excise taxes should comprise at least $70 \%$ of the final retail price, as recommended by the WHO. ${ }^{4}$ In 2020, 52 countries reported having a specific-only excise tax on tobacco, but only 30 met the Framework Convention on Tobacco Control criteria of having excise taxes that comprised $70 \%$ of the final price. ${ }^{23}$ Finally, regular tax increases ensure that taxes continue to make up a substantial portion of price and meaningfully influence behaviour, even under circumstances of high inflation and/ or increased consumer wage growth. Substantial, repeated tax increases have been shown to have reduced tobacco use in many low/middle-income countries, including Brazil, ${ }^{24}$ Turkey $^{25}$ and the Philippines. ${ }^{26}$ Large unannounced increases may have even larger effects, denying tobacco companies the opportunity to prepare for the increases. ${ }^{27}$

In Australia and New Zealand, taxes are simple in structure and the specific excise duty has been increased annually for 8 consecutive years: by $12.5 \%$ each year in Australia on top of adjustments for wage growth and by $10 \%$ each year in New Zealand in real terms, ${ }^{28}{ }^{29}$ taking taxes in these countries to the highest in the world. ${ }^{23}$ Tax increases have been associated with falls in prevalence in both countries ${ }^{3031}$ The volume of tobacco products cleared by tax authorities for home consumption was approximately 32\% lower per capita in Australia in 2019/2020 than it was in $2013^{29}$ and has also fallen markedly in New Zealand. $^{32}$

\section{MINIMUM PRICING ESTABLISHED THROUGH MINIMUM PRICE LAWS AND/OR MINIMUM EXCISE TAXES}

Minimum price laws (MPLs) set a legislated price below which a specific tobacco product cannot be sold. In the USA, 
MPLs originated as an outgrowth of minimum mark-up laws, established in the USA in the mid-1900s to prevent large retailers from selling cigarettes below cost in order to price small retailers out of the market. These minimum mark-up laws require mark-ups on the base cost of a product. ${ }^{33} 34$ Base costs are derived from wholesaler and retailer invoices, which vary, so these policies do not result in a single statutorily set minimum, but rather vary based on the actual wholesale price. Given that some stores sell hundreds of brands and brand variants, each with their own wholesale price and therefore with mark-ups and final prices of varying dollar value, minimum mark-up laws can be difficult to implement and enforce. More recently, some jurisdictions-rather than imposing a minimum mark-up-have instead established a single floor price, not tied to a base cost, below which no products can be retailed.

MPLs designed with floor prices limit the tobacco industry's ability to maintain lower-priced products by reducing tax passthrough, as each product on the market cannot be sold below the legislated minimum. When a floor price is set high enough, MPLs could eliminate the sale of discount brands altogether, while potentially leaving prices of premium, expensive products relatively unchanged. Smokers who are particularly price sensitive, including those with limited incomes, might therefore be particularly responsive to MPLs. Alcohol research provides some support for this hypothesis; following the 2018 introduction of minimum unit alcohol pricing, alcohol prices increased in Scotland and consumption decreased the most in lower-income households. ${ }^{35}$

Real-world evidence in support of tobacco MPLs, however, is limited. Although hypothetical and simulation studies suggest smokers, including lower-income consumers, would reduce consumption following the implementation of an MPL set above the average market price, ${ }^{36-39}$ only a few implemented MPLs have been evaluated. Two studies of US mark-up laws found little support that they were associated with higher average cigarette prices, except when price promotions were also banned, ${ }^{34} 40$ although a third found evidence to suggest mark-up laws were associated with higher prices for lowerpriced products. ${ }^{41}$ Malaysia adopted a minimum floor price of 6.40 ringgit (US\$1.88) in 2010; in 2011, this was raised to 7.00 ringgit (US\$2.31). A small reduction in licit sales below the legislated minimum followed, and there was also a small increase in average prices for those sales. However, more than $96 \%$ of licit sales were already above the minimum before implementation. ${ }^{42}$ In 2014, New York City established a $\$ 10.50$ minimum price for a pack of 20 cigarettes. An audit study documented very high policy compliance for a premium cigarette brand, ${ }^{43}$ but, similarly, this is unsurprising since the floor price was set 70 cents below the average price prepolicy. ${ }^{44}$ In 2018, as part of a suite of tobacco control policies, New York City raised the cigarette floor price to $\$ 13.00$ and established floor prices for six other tobacco products ${ }^{44}$; the effects of these new and increased floor prices have not yet been formally evaluated.

The type of MPL implemented in Malaysia and New York City raises concerns among some tobacco control advocates because they may increase profits for retailers or tobacco companies. In some countries, the tobacco industry has actively supported minimum pricing policies, perhaps as a strategy to keep lower-priced competitors out of the market. ${ }^{42}{ }^{45}$ Similarly, MPLs can be viewed by lawmakers as stifling competition, and therefore not politically or legally feasible. ${ }^{46}$

One proposed alternative method of setting a price minimum, currently implemented by nearly 50 countries, ${ }^{4}$ is a minimum excise tax (MET), which ensures a minimum amount of taxation on each product, regardless of its wholesale price. The UK implemented this approach in 2017, adding a MET to its existing specific and ad valorem taxes on factory-made cigarettes ${ }^{47}$ and complementing its ban on all promotions of tobacco products that was put in place in $2003 .^{48}$ This means that, in 2021, cigarettes in the UK generally attract duty of $£ 244.78$ per 1000 cigarettes, plus $16.5 \%$ of final retail price. However, if the duty on a pack of cigarettes under that formula would work out to be less than $£ 320.90$ per 1000 cigarettes in total, then the higher duty level (ie, $£ 320.90$ per 1000 cigarettes) applies. In the period following the implementation of the MET, prices on the lowest price factory-made cigarettes increased significantly. ${ }^{47}$

Because MPLs and METs can effectively increase prices at the lower end of the market, which policy a government opts to implement may be a political or logistical decision. METs may be a good alternative to MPLs in places where MPLs are not legally feasible, in places with concerns about generating revenues for retailers or tobacco companies, and in places where tax levels already comprise a significant component of the overall product price. METs, however, require a strong, well-designed, well-implemented and well-enforced excise tax system, because the implementation of minimum excise taxes tends to be more administratively complex, particularly in places with multi-tiered mixed tobacco tax systems. In addition, METs may potentially exacerbate the price differentials between products with similar risks, if products with similar risk profiles are taxed at different rates. MPLs may therefore be a more straightforward, administratively simpler approach that reduces unintended substitution between different products, especially in places where taxation is politically unpopular or tobacco tax systems are complex or poorly designed.

\section{BAN ON COUPONS AND PROMOTIONS}

Coupons and price promotions can substantially reduce the price of tobacco products. Policies to restrict price promotions typically outlaw the distribution or redemption of coupons that lower the price of tobacco products or prohibit the offering of one or more free packs when selling a pack at full price.

As of 31 December 2018, the WHO Report shows that 113 countries $^{4}$ out of 195 had banned promotional discounts. Many of these countries are banning promotional discounts as part of a broader ban on all tobacco product advertising. In the USA, states are not allowed to ban manufacturers from offering coupons, but they can ban the redemption of coupons at retailers in their jurisdiction. ${ }^{49}$ Coupon restrictions may also be used in conjunction with minimum pricing such that regulations ${ }^{4950}$ prohibit the retailer from accepting coupons that lower the price below the MPL floor price or MET.

Point-of-sale tobacco advertising and product displays are banned in Australia, but price boards listing the names and prices of available products are allowed in most states. Over time, the boards have become more common and are less often being organised alphabetically and more often organised by price, with value brands listed first. ${ }^{51}$ This suggests that price boards could be a potential loophole to marketing restrictions and should be curtailed. Policymakers may also want to consider banning contracts and agreements between tobacco companies and retailers ${ }^{52}$ to prevent companies from manipulating product placement or promoting lower-priced products. After a display ban in Scotland, tobacco retailers received incentives for prime product placement behind the 
Table 1 Advantages of tobacco control policies that raise cigarette prices

\begin{tabular}{|c|c|c|c|c|c|c|c|}
\hline $\begin{array}{l}\text { Factors for assessing pricing } \\
\text { policies }\end{array}$ & $\begin{array}{l}\text { Large increases } \\
\text { in excise duty }\end{array}$ & $\begin{array}{l}\text { Large increase in duty plus } \\
\text { harmonisation (across } \\
\text { products and places) }\end{array}$ & $\begin{array}{l}\text { Minimum } \\
\text { pricing }\end{array}$ & $\begin{array}{l}\text { Minimum } \\
\text { excise tax }\end{array}$ & $\begin{array}{l}\text { Ban on price } \\
\text { promotion }\end{array}$ & $\begin{array}{l}\text { Three policies } \\
\text { combined }\end{array}$ & $\begin{array}{l}\text { Three policies plus } \\
\text { harmonisation }\end{array}$ \\
\hline $\begin{array}{l}\text { Administrative simplicity and ease of } \\
\text { implementation and enforcement }\end{array}$ & $\checkmark \checkmark \checkmark$ & $\checkmark \checkmark \checkmark$ & $\checkmark \checkmark$ & $\checkmark \checkmark$ & $\checkmark$ & $\checkmark$ & $\checkmark$ \\
\hline $\begin{array}{l}\text { Reduced capacity for industry price } \\
\text { manipulation }\end{array}$ & $\checkmark$ & $\checkmark \checkmark$ & $\checkmark \checkmark$ & $\checkmark \checkmark$ & $\checkmark \checkmark$ & $\checkmark \checkmark$ & $\checkmark \checkmark \checkmark$ \\
\hline $\begin{array}{l}\text { Effectiveness in reducing availability of } \\
\text { very cheap products }\end{array}$ & $\checkmark$ & $\checkmark \checkmark$ & $\checkmark \checkmark$ & $\checkmark \checkmark$ & $\checkmark \checkmark$ & $\checkmark \checkmark \checkmark$ & $\checkmark \checkmark \checkmark$ \\
\hline $\begin{array}{l}\text { Additional revenue for government } \\
\text { which can be directed to cessation } \\
\text { services for low-income smokers }\end{array}$ & $\checkmark \checkmark$ & $\checkmark \checkmark \checkmark$ & & $\checkmark \checkmark$ & & $\checkmark \checkmark \checkmark$ & $\checkmark \checkmark \checkmark$ \\
\hline $\begin{array}{l}\text { Overall potential effectiveness in } \\
\text { reducing inequities between low and } \\
\text { high-income groups }\end{array}$ & $\checkmark$ & $\checkmark \checkmark$ & $\checkmark$ & $\checkmark$ & $\checkmark$ & $\checkmark \checkmark \checkmark$ & $\checkmark \checkmark \checkmark$ \\
\hline $\begin{array}{l}\text { Overall potential effectiveness in } \\
\text { reducing smoking }\end{array}$ & $\checkmark \checkmark$ & $\checkmark \checkmark$ & $\checkmark$ & $\checkmark$ & $\checkmark$ & $\checkmark \checkmark$ & $\checkmark \checkmark \checkmark$ \\
\hline
\end{tabular}

$\checkmark=$ slightly addresses this issue; $\checkmark \checkmark=$ moderately addresses; $\checkmark \checkmark \checkmark=$ strongly addresses.

display flap, including placing lower-priced products near more expensive ones so that consumers see them when the flap is briefly opened to retrieve the product. ${ }^{53}$

\section{IMPLEMENTATION OF THE THREE-PRONGED APPROACH: CHALLENGES AND OPPORTUNITIES}

Lower-priced tobacco products remain on the market, even in countries where excise taxes are very high. The threepronged comprehensive pricing policy approach outlined above combines the advantages of each of three different policies, while at the same time offsetting each policy's limitations related to the maintenance of a lower-priced product market (table 1). We note a few of these in table 1 , focusing on strengths and weaknesses related to market segmentation and recognising that our goal is not to maximise revenue for governments or necessarily to reduce profit for tobacco companies but rather to address the problems posed by widespread availability of lower-priced products. Unfortunately, no country has yet implemented such an approach, so real-world evaluations will be needed to ascertain whether the combined policies can achieve this goal. To enhance potential effectiveness, we offer several potential issues for consideration should jurisdictions explore this three-pronged approach.

\section{The need for harmonisation of policies across all products}

Even with multiple pricing policies, product switching will continue to be a problem unless policies are applied to all tobacco products. In Australia, price discounting is still allowed and there are no MPLs, but couponing and most other forms of promotion are banned, ${ }^{54}$ and the excise duty increased by $135 \%$ in the period $2013-2020 .^{28}$ Nevertheless, the price of a pack of the leading brand of cigarettes in 2020 was only $57 \%$ higher than the price of a pack of the leading brand in 2013. ${ }^{55}$ Furthermore, many products-including small pouches of RYO tobacco and super-value cigarette productsremain affordable to most consumers. The percentage of adult current smokers using any RYO rose from $32.3 \%$ in 2010 to $44.8 \%$ in $2019 .{ }^{56}$ While prevalence of daily smoking fell from $15.9 \%( \pm 0.6 \%)$ of adults in 2010 to $11.6 \%( \pm 0.6)$ in $2019,^{56}$ harmonising tax policies to ensure similar levels of excise duty were payable on RYO products as on the equivalent number of manufactured cigarettes would likely have resulted in greater reductions in tobacco use. ${ }^{5758}$

\section{The need for cooperation across jurisdictions}

Even with strong price policies, retailers and consumers can engage in policy avoidance, especially if lower price markets are nearby. For example, New York City currently bans the redemption of coupons or other price promotions, has a minimum price law for cigarettes and multiple other tobacco products, and has a specific excise tax that, while modest by some international standards, is among the highest in the USA. ${ }^{44}$ Although adult smoking prevalence dropped substantially in New York City over the last two decades, $11.9 \%$ of adults still smoked in 2020, and socioeconomic and other disparities remain. ${ }^{59}$ New York City is geographically small, and is within easy driving distance of places with substantially lower taxes and no additional pricing policies. As a result, cross-border purchasing and smuggling produces an illicit market for lower-priced products. ${ }^{6061}$ In other places, in the absence of harmonised policies, consumers are able to travel outside of their jurisdiction with less restrictive price policies or to discount outlets where bulk purchasing is available to maintain lower prices. ${ }^{7}$ Lopez-Nicolas and Branston have recently suggested that European Union (EU) minimum tax laws be set to a minimum percentage of the average price across all EU countries. This would increase prices in countries where taxes and prices are currently low, reducing consumption in those countries, reducing incentives for cross-border shopping and generating revenues that could be used for public health. ${ }^{58}$

\section{The need to support lower-income smokers}

Although our focus is on reducing lower-priced market segments, the three-pronged approach may help counter other concerns about individual price policies. One critique of non-tax price policies, for example, is that by not generating revenue for governments, they may not support the funding of cessation or other public health efforts. This is less of an issue when a non-tax price policy is paired with an excise tax increase making additional government revenue available for cessation services. Such support is particularly critical for low-income countries, which may rely on tobacco taxes for funding other tobacco control efforts, and for lower-income smokers, who may face financial hardship in light of increasing tobacco prices if they continue to smoke. ${ }^{62}$ Although tobacco tax increases are sometimes criticised as regressive, ${ }^{63} 64$ in fact they can be progressive if they result in higher proportions 
of low-income smokers quitting smoking. ${ }^{65}$ Because they discourage a shift to the lower-priced products, minimum tax or pricing laws and bans on price promotion most likely would increase the progressive effects of tax increases in encouraging low-income smokers to quit. In addition, a large proportion of those smokers who do not quit will likely reduce the number of cigarettes they smoke per day. While this is unlikely to reduce their risks of disease, it may well increase their probability of success for future quit attempts.

\section{The need for enforcement}

Although the three-pronged price policy guards against the drawbacks of an excise tax increase in isolation, it may be more difficult to introduce in a jurisdiction where there are high levels of use of illicit tobacco or in jurisdictions that have weaker tax administration systems. Nevertheless, raising excise taxes creates new revenue streams that can be earmarked to increase staffing and expand systems for tax administration.

\section{CONCLUSION}

Governments around the globe have made great strides in tobacco control over the past five decades, in large part due to strong tobacco tax policies that have increased the price of cigarettes. However, lower-income smokers around the world continue to face a high tobacco burden with continued availability of lower-priced tobacco products. Strengthening excise tax policies to ensure they are applied equally to all combustible products, that they account for a significant portion of product prices and that they are supplemented with laws that minimise the availability of lower-priced products holds great promise for reducing socioeconomic disparities. Intentionally implemented together, these measures could go beyond a simple three-pronged approach, to become a troika of tobacco pricing policy-working together to synergistically turbocharge tobacco control towards the endgame.

\section{What this paper adds}

- Although tobacco excise taxes increase prices and reduce consumption, the tobacco industry may overshift the tax to more expensive products and offer coupons and price discounts to ensure lower-priced products remain available.

- Tobacco industry tactics allow price-sensitive consumers, including lower-income smokers, to practise price-minimising behaviours that undercut the impact of a tobacco excise tax increase.

- A three-pronged approach, whereby substantial specific excise tax increases are paired with minimum price laws and bans on coupons and price promotions, has the potential to reduce disparities in smoking rates between lower-income and higher-income groups.

- Few jurisdictions currently implement this threepronged approach, but lessons can be learnt from places implementing it.

\section{Twitter Kurt M Ribisl @KurtRibisl and Jidong Huang @JidongHuang}

Contributors KMR conceived of the idea. All authors contributed by drafting sections, editing and approving the final version.

Funding Research reported in this publication was supported by the National Cancer Institute of the National Institutes of Health under Award number P01 CA225597 (KMR and SDG).

Disclaimer The funders had no involvement in the writing or interpretation.
Competing interests MS's work for the Centre for Behavioural Research in Cancer is supported by funding from the Cancer Council Victoria. KMR is a paid expert consultant in litigation against tobacco companies.

Patient consent for publication Not required.

Ethics approval This study does not involve human participants.

Provenance and peer review Commissioned; externally peer reviewed.

\section{ORCID iDs}

Kurt M Ribisl http://orcid.org/0000-0003-3318-8524

Shelley Diane Golden http://orcid.org/0000-0002-3283-542X

Jidong Huang http://orcid.org/0000-0002-3425-9155

Michelle Scollo http://orcid.org/0000-0002-6583-4730

\section{REFERENCES}

1 Acharya A, Angus K, Asma S, et al. The economics of tobacco and tobacco control, 2016.

2 IARC Working Group on the Effectiveness of Tax Price Policies for Tobacco Control International Agency for Research on Cancer. Effectiveness of Tax and price policies for tobacco control, 2012.

3 U.S. National Cancer Institute and World Health Organization. The economics of tobacco and tobacco control. Bethesda, MD: U.S. Department of Health and Human Services, National Institutes of Health, National Cancer Institute; and Geneva, $\mathrm{CH}$ : World Health Organization, 2016.

4 World Health Organization. WHO report on the global tobacco epidemic, 2019: offer help to quit tobacco use: World Health organization, 2019.

5 Huang J, Zheng R, Chaloupka FJ, et al. Chinese smokers' cigarette purchase behaviours, cigarette prices and consumption: findings from the ITC China survey. Tob Control 2014;23 Suppl 1:i67-72.

6 Licht AS, Hyland AJ, O'Connor RJ, et al. Socio-Economic variation in price minimizing behaviors: findings from the International tobacco control (ITC) four country survey. Int J Environ Res Public Health 2011;8:234-52.

$7 \mathrm{Xu}$ X, Pesko MF, Tynan MA, et al. Cigarette price-minimization strategies by U.S. smokers. Am J Prev Med 2013;44:472-6.

8 US Federal Trade Commission. Federal Trade Commission cigarette report for 2019 and smokeless tobacco report for 2019, 2020.

9 Choi K, Soneji S, Tan ASL. Receipt of tobacco direct mail Coupons and changes in smoking status in a nationally representative sample of US adults. Nicotine Tob Res 2018;20:1095-100.

10 Ribisl KM, D'Angelo H, Feld AL, et al. Disparities in tobacco marketing and product availability at the point of sale: results of a national study. Prev Med 2017:105:381-8.

11 Spanopoulos D, Ratschen E, McNeill A, et al. Retail price and point of sale display of tobacco in the UK: a descriptive study of small retailers. PLoS One 2012;7:e29871.

12 Henriksen L, Schleicher NC, Johnson TO, et al. Mind the gap: changes in cigarette prices after California's Tax increase. Tob Regul Sci 2019;5:532-41.

13 Gilmore AB, Tavakoly B, Taylor G, et al. Understanding tobacco industry pricing strategy and whether it undermines tobacco Tax policy: the example of the UK cigarette market. Addiction 2013;108:1317-26.

14 Hiscock R, Branston JR, McNeill A, et al. Tobacco industry strategies undermine government Tax policy: evidence from commercial data. Tob Control 2018;27:488-97.

15 Wilson LB, Pryce R, Hiscock R, et al. Quantile regression of tobacco Tax pass-through in the UK 2013-2019. How have manufacturers passed through Tax changes for different tobacco products? Tob Control 2021;30:e27-32.

16 Dunlop SM, Perez D, Cotter T. Australian smokers' and recent quitters' responses to the increasing price of cigarettes in the context of a tobacco Tax increase. Addiction 2011;106:1687-95.

17 Betzner A, Boyle RG, St Claire AW. Price-Minimizing behaviors in a cohort of smokers before and after a cigarette Tax increase. Int J Environ Res Public Health 2016;13. doi:10.3390/ijerph13060608. [Epub ahead of print: 1706 2016].

18 Demjén T, Kiss J, Kovács PA, et al. The purchase sources of and price paid for cigarettes in six European countries: findings from the EUREST-PLUS ITC Europe surveys. Tob Induc Dis 2018;16:A16.

19 Cornelius ME, Driezen P, Hyland A, et al. Trends in cigarette pricing and purchasing patterns in a sample of US smokers: findings from the ITC us surveys (2002-2011). Tob Control 2015;24 Suppl 3:iii4-10.

20 Greenberger E. Survey measures for the study of work, parenting, and well-being, 1989: 3-43.

21 World Health Organization. Who technical manual on tobacco Tax policy and administration. Geneva: WHO, 2021

22 Shang C, Chaloupka FJ, Fong GT, et al. The association between Tax structure and cigarette price variability: findings from the ITC project. Tob Control 2015;24 Suppl 3:iii88-93.

23 Framework Convention on Tobacco Control Secretariat. B821 - Only specific tax levied. Geneva: World Health Organization, 2021 
24 Gigliotti A, Figueiredo VC, Madruga CS, et al. How smokers may react to cigarette taxes and price increases in Brazil: data from a national survey. BMC Public Health 2014; $14: 327$.

25 Cetin T. The effect of taxation and regulation on cigarette smoking: fresh evidence from turkey. Health Policy 2017;121:1288-95.

26 Cheng KJG, Estrada MAG. Cost-Effectiveness analysis of the 2019 cigarette excise tax reform in the Philippines. Prev Med 2021;145:106431.

27 Hiscock R, Branston JR, McNeill A, et al. Tobacco industry strategies undermine government Tax policy: evidence from commercial data. Tob Control 2018;27:488-97.

28 Scollo M, Bayly M. 13.2 tobacco taxes in Australia. Melbourne: Cancer Council Victoria, 2021.

29 Scollo M. Table 2.2.5b Cigarettes and smoking tobacco on which duties were levied (excise and customs combined) — total cigarettes (ready-made and roll-your-own) and cigarettes per person 15 years and over, 2011 to 2020 (estimated numbers of cigarettes). Melbourne: Cancer Council Victoria, 2021.

30 Wilkinson AL, Scollo MM, Wakefield MA, et al. Smoking prevalence following tobacco tax increases in Australia between 2001 and 2017: an interrupted time-series analysis. Lancet Public Health 2019;4:e618-27.

31 Tucker MR, Kivell BM, Laugesen M, et al. Changes to smoking habits and addiction following tobacco excise tax increases: a comparison of Māori, Pacific and New Zealand European smokers. Aust N Z J Public Health 2017;41:92-8.

32 Health Promotion Agency. Tobacco control data Repository.

33 Centers for Disease Control and Prevention (CDC). State cigarette minimum price laws - United States, 2009. MMWR Morb Mortal Wkly Rep 2010;59:389-92.

34 Tynan MA, Ribisl KM, Loomis BR. Impact of cigarette minimum price laws on the retail price of cigarettes in the USA. Tob Control 2013;22:e78-85.

35 O'Donnell A, Anderson P, Jané-Llopis E, et al. Immediate impact of minimum unit pricing on alcohol purchases in Scotland: controlled interrupted time series analysis for 2015-18. BMJ 2019;366:15274.

36 Critchlow N, Moodie C, Best C, et al. Anticipated responses to a hypothetical minimum price for cigarettes and roll-your-own tobacco: an online crosssectional survey with cigarette smokers and ex-smokers in the UK. BMJ Open 2021;11:e042724.

37 Doogan NJ, Wewers ME, Berman M. The impact of a federal cigarette minimum pack price policy on cigarette use in the USA. Tob Control 2018;27:203-8.

38 Golden SD, Farrelly MC, Luke DA, et al. Comparing projected impacts of cigarette floor price and excise tax policies on socioeconomic disparities in smoking. Tob Control 2016;25:i60-6.

39 Marynak KL, Xu X, Wang $X$, et al. Estimating the impact of raising prices and eliminating discounts on cigarette smoking prevalence in the United States. Public Health Rep 2016;131:536-43.

40 Feighery EC, Ribisl KM, Schleicher NC, et al. How do minimum cigarette price laws affect cigarette prices at the retail level? Tob Control 2005;14:80-5.

41 Huang J, Chriqui JF, DeLong $\mathrm{H}$, et al. Do state minimum markup/price laws work? Evidence from retail scanner data and TUS-CPS. Tob Control 2016;25:i52-9.

42 Liber AC, Ross H, Omar M, et al. The impact of the Malaysian minimum cigarette price law: findings from the ITC Malaysia survey. Tob Control 2015;24 Suppl 3:iii83-7.

43 Silver D, Bae JY, Jimenez G, et al. Compliance with minimum price and legal age for cigarette purchase laws: evidence from NYC in advance of raising purchase age to 21 . Tob Control 2016:25:289-94.

44 Schroth KRJ. Increasing price and reducing access to tobacco in New York City. J Law Med Ethics 2019:47:87-90.
45 Albuja S, Daynard RA. The framework convention on tobacco control (FCTC) and the adoption of domestic tobacco control policies: the Ecuadorian experience. Tob Control 2009;18:18-21.

46 Chaloupka FJ. Commentary on Ross et al. (2011): Beyond cigarette taxes - the need for research on other cigarette pricing policies. Addiction 2011;106:620-1.

47 Hiscock R, Augustin NH, Branston JR, et al. Standardised packaging, minimum excise tax, and RYO focussed Tax rise implications for UK tobacco pricing. PLoS One 2020;15:e0228069.

48 Harris F, MacKintosh AM, Anderson S, et al. Effects of the 2003 advertising/promotion ban in the United Kingdom on awareness of tobacco marketing: findings from the International tobacco control (ITC) four country survey. Tob Control 2006;15 Suppl 3:iii26-33.

49 Public Health and Tobacco Policy Center. Tobacco price promotion: local regulation of discount Coupons and certain value-added sales, 2013.

50 McLaughlin I, Pearson A, Laird-Metke E, et al. Reducing tobacco use and access through strengthened minimum price laws. Am J Public Health 2014;104:1844-50.

51 Bayly M, Scollo M, White S, et al. Tobacco price boards as a promotional strategy-a longitudinal observational study in Australian retailers. Tob Control 2018;27:427-33.

52 Feighery EC, Ribisl KM, Clark Pl, et al. How tobacco companies ensure prime placement of their advertising and products in stores: interviews with retailers about tobacco company incentive programmes. Tob Control 2003;12:184-8.

53 Stead M, Eadie D, Purves RI, et al. Tobacco companies' use of retailer incentives after a ban on point-of-sale tobacco displays in Scotland. Tob Control 2018;27:414-9.

54 Grace C. 11.4 state and territory legislation. Melbourne: Cancer Council Victoria, 2018.

55 Scollo M, Bayly M. 13.3 the price of tobacco products in Australia. Melbourne: Cancer Council Victoria, 2021.

56 Australian Institute of Health and Welfare. Data tables: National Drug Strategy Household Survey 2019 - 2. Tobacco smoking chapter, Supplementary data tables. Canberra: AlHW, 2020.

57 Excise tariff Amendment (tobacco duty harmonisation) act 2017, 2017.

58 López-Nicolás Ángel, Branston JR. Promoting convergence and closing gaps: a blueprint for the revision of the European Union tobacco Tax Directive. Tob Control 2021. doi:10.1136/tobaccocontrol-2021-056496. [Epub ahead of print: 24 May 2021].

59 Gallahue P, Merlino V. Adult smoking rate in NYC declines; reaches take care New York 2020 target. City of New York, 2020.

60 Chernick H, Merriman D. Using littered pack data to estimate cigarette Tax avoidance in NYC. Natl Tax J 2013;66:635-68.

61 Shelley D, Cantrell MJ, Moon-Howard J, et al. The \$5 man: the underground economic response to a large cigarette tax increase in New York City. Am J Public Health 2007:97:1483-8.

62 Wilson N, Thomson G. Tobacco taxation and public health: ethical problems, policy responses. Soc Sci Med 2005;61:649-59.

63 Warner KE. The economics of tobacco: myths and realities. Tob Control 2000;9:78-89.

64 Remler DK. Poor smokers, poor quitters, and cigarette Tax regressivity. Am J Public Health 2004;94:225-9.

65 Verguet S, Kearns PKA, Rees VW. Questioning the regressivity of tobacco taxes: a distributional accounting impact model of increased tobacco taxation. Tob Control 2021;30:245-57. 